\title{
COVID-19: Issues/Lessons
}

\begin{abstract}
Although by the pace of the events, COVID-19 pandemic is still ravaging the human population and it is far from its end, that is, from the epidemiological control, it is already acceptable to infer that its consequences may be comparable, or even greater, than the effects of the two World Wars, in terms of affected people, deaths, and psychosocial after-effects. Of course, it is still very difficult, or even impossible, to assess the entire "pool" of physical, social, and economic damages, including the exchange of ideas, goods and services within and among geographical areas on different scales (local, National, and Continental) in the face of major restrictions arising from the sanitary measures imposed to reduce the spread of the virus or immediately resulting from the disease, mobilizing hundreds of millions of people and their families for care in their homes, clinics, or hospital centers.

The simple enunciation of these topics already highlights, effectively or potentially, the enormous and even immeasurable balance of events with mixed signals (negative and eventually positive), and it is notorious that, within the framework of antagonisms that characterize the emergence and evolution of the pandemic, one can glimpse the heavily adverse balance in relation to the objectives of the so-called human development. ${ }^{1}$ That is, the material progress, the increasing and equitable access to exchange principles and conquests that, in still ideal terms, define and provide the state of individual and collective wellbeing. Under these conditions, the genetically possible full physical and psychosocial development would be fulfilled, defining the achievement on economic, social, political, ethical, participatory, creative, and even spiritual attributes, within a standard of respect for the natural environment (ecology) and under a condition of sustainability, taking into account the legacy that is, due to, future generations.

Resuming to the coronavirus: it is clear that, the great demand of questions and lessons applies in the health sector. In fact, the discovery of a new nosology problem, singularized by its high capacity of transmission, pathogenic effects, and practically universal susceptibility, has imposed an overload on all sectors that make up the health/disease binomial, opening a crisis that starts from the concept itself and spreads to all spaces, requiring innovative methods to research, diagnose, treat, and prevent. These are new and surprising challenges imposed on the dualism of time/space. Where to start, how and when to intervene? actually within a few weeks and months, the pandemic spread to every corner of the planet: local communities, States, and Continents, becoming a global medical/health emergency. ${ }^{2}$ From one moment to another, models and table attempts were opened and occupiedto register the new pandemic. Within weeks and months, tens of millions of people were affected so much, that by this week, 178 million cases have made up the impressive statistics known on a worldwide scale, leading to 3,873.255 deaths. In Brazil, until last week, COVID-19 led more than 500,000 deaths, a total of $17,976.510$ confirmed cases. ${ }^{3}$ With these indicators, Brazil becomes the second country in the world with the highest number of deaths, approaching the United States, which still occupies first place. As our moving averages of incident cases and deaths per week have increased between 10 and $20 \%$, the projection is that we may soon overtake the United States.

Truly, we are still perplexed and senseless. Quite different from China's history where, after the first pioneering cases were described and communicated to the World Health Organization (WHO) from the province
\end{abstract}


of Wuhan, there already was a work proposal. Thus, based on the principles of analogy, research protocols and treatment procedures were established, indicating the handling of cases in the hospitals, outpatient clinics, and in the fa-mily environment. In short: even in an unprecedentedness situation, less than 10 months later, the pandemic was practically under control. 4

Thanks to WHO, which went from a conventional advisory body to countries on all continents assuming a very active role, structuring communication chains that almost daily broadcast technical bulletins about the problem and its consequences, conferences, and debates to face the new pandemic, which no other health problem has ever been treated with such depth. It is indeed an extension work that should be recognized, including for its multi-professional approach: epidemiology, infectology, pneumology, psychology, service management, and other activities and agents.

Unfortunately, we are facing new threats. New strains of coronavirus have been identified in various parts of the world, as in the case of Delta variant, present in $91 \%$ of the mutation cases, thus, becoming dominant. 5 How does the immunological efficacy of vaccines behave with these changes? This is still an open question. In fact, given to the current uncertainties, several countries are already planning a booster dose of vaccine, as in the United Kingdom. On the other hand, several other countries are already adopting more liberal rules, such as the abandonment of masks and participation in sporting events, wide access to entertainment venues and commercial establishments. Even though this liberalization is questionable, Brazil is already adopting, perhaps precociously, these measures, such as face to face attendance in public and private schools.

A very unfavorable observational fact: the conduct of omission, disinterest, and even disapproval from government agents in facing the pandemic. In Brazil, there is a case of a long negotiation: six months (and still not concluded) in purchasing vaccines that if had been applied earlier it could have changed the course of the pandemic, avoiding tens of millions of cases and perhaps spared 150,000 to 200,000 deaths. Considering that coronavirus as a "little flu", wasting time and money on ineffective drugs, disregarding protective actions, such as isolation, and promoting unjustified agglomerations is, in fact, a severe disservice to the population in this country.

\section{References}

1. Assembly, General. Resolution adopted by the General Assembly on 6 July 2017. A/RES/71/313, 2017. [acesso 23 jun 2021]. Disponível em: http://ggim.un.org/meetings/2017-4th_Mtg_IAEG-SDG-NY/documents/A_RES_71_313.pdf

2. Agência Brasil. Organização Mundial da Saúde declara pandemia de coronavírus, Brasília, 11 jun. 2020. [acesso 23 jun 2021 ]. Disponível em: https://agenciabrasil.ebc.com.br/geral/noticia/2020-03/organizacao-mundial-da-saude-declara-pandemia-de-coronavirus

3. DASA ANALYTICS. Dados COVID-19. [acesso 22 jun 2021]. Disponível em: https://dadoscoronavirus.dasa.com.br/

4. Xumao Zhao, Xinhai LI, Changhong NIE. Backtracking transmission of COVID-19 in China based on big data source, and effect of strict pandemic control policy. Bull Chin Acad Sci. 2020; 35 (3): 248-55.

5. Lisboa V. Agência Brasil. Covid-19: pesquisa detecta nova variante em 91\% dos casos no Amazonas, Rio de Janeiro, 29 jan. 2021. [acesso 23 jun 2021]. Disponível em: https://agenciabrasil.ebc.com.br/saude/noticia/2021-01/covid-19-pesquisa-detecta-novavariante-em-91-dos-casos-no-amazonas

Malaquias Batista Filho 1

(iD https://orcid.org/0000-0002-1490-0590

Déborah Lemos Freitas 2

(iD) https://orcid.org/0000-0002-6068-8623

1,2 Instituto de Medicina Integral Prof. Fernando Figueira. Rua dos Coelhos, 300. Boa Vista. Recife, PE, Brazil. CEP: 50.070-902. 